\title{
少子化社会における非正規雇用と結婚，妊娠・出産，育児
}

\author{
錦谷まりこ ${ }^{1}$, 井上まり子 ${ }^{2}$, 鶴ヶ野しのぶ ${ }^{3}$ \\ 1 九州大学持続可能な社会のための決断科学センター \\ 2 帝京大学大学院公衆衛生学研究科 \\ 3 電気通信大学保健管理センター
}

\section{Nonregular Employment in a Society with a Decreasing Birthrate: Workers' Marriage, Childbirth, and Childcare}

\author{
Mariko NISHIKITANI ${ }^{1}$, Mariko INOUE ${ }^{2}$ and Shinobu TSURUGANO \\ ${ }^{1}$ Institute of Decision Science for a Sustainable Society, Kyushu University \\ ${ }^{2}$ Graduate School of Public Health, Teikyo University \\ ${ }^{3}$ Health Care Center, The University of Electro-Communications
}

\begin{abstract}
In this paper, we examine the trend in Japan towards nonregular employment and its effects on marriage, childbirth, and childcare from the viewpoint of a decreasing societal birthrate. Although the decision to marry includes personal values and preferences, socioeconomic status factors such as income and employment type are also associated with the determinants of marriage. Nonregular employment workers have a lower rate and motivation for marriage than regular workers. Thus, socioeconomic disparity caused by employment needs to be minimized through governmental measures and policies. Nonregular employment is increasing among younger generations, and for them, maternity and childcare leave are especially vital. Employee insurance coverage should be expanded to function as a form of income security during these leaves of absence, such that nonregular workers are also covered. During the childcare period, which lasts more than 10 years, it is necessary to cover childrearing costs and also the time required to spend with children. If a single working parent is involved in childcare alone, there is the burden of both work and childcare. Additionally, long work hours can also impact workers that are not involved in childcare. This is a dilemma: a stable and regular employment is often necessary to achieve a higher education; however, it is difficult for nonregular employees to take care of and prepare children for higher education owing to limited financial means. Properly designed measures and policies are necessary to break this chain. Importantly, considerations about life and work are important for all workers, including nonregular workers, who are especially affected in terms of marriage, childbirth, and childcare.
\end{abstract}

Key words: nonregular employment（非正規雇用), marriage（結婚）, childbirth（妊娠・出産）, childcare (育览), decreasing birthrate（少子化）

受付 2017 年 10 月 18 日, 受理 2018 年 2 月 5 日 Reprint requests to: Mariko NISHIKITANI, MPH, PhD

Institute of Decision Science for a Sustainable Society, Kyushu University, 3-1-1 Maidashi, Higashi-ku, Fukuoka 812-8582, Japan TEL \& FAX: +81(92)642-6475

E-mail: makorin@med.kyushu-u.ac.jp
連載の今回は非正規雇用と少子化との関係を，子供の 生じる基盤となるカップルの社会的結びつき( I . 結婚) から，子供を産む時期（II. 妊娠・出産），そして生ま れた子供の養育（III. 育児）の3 段階に分けてそれぞれ 1. 現状と課題，2. 関連した研究からのエビデンスを提 
表 1 日本の非正規雇用労働者（2016 年）

\begin{tabular}{lrrrr}
\hline & \multicolumn{2}{c}{ 男性 } & \multicolumn{2}{c}{ 女性 } \\
\hline $15 \sim 19$ 歳 (在学中を除く) & 9 万人 & $30.0 \%$ & 7 万人 & $38.9 \%$ \\
$20 \sim 24$ 歳(在学中を除く) & 36 万人 & $23.8 \%$ & 50 万人 & $31.3 \%$ \\
$25 \sim 29$ 歳 & 50 万人 & $18.7 \%$ & 80 万人 & $35.3 \%$ \\
$30 \sim 34$ 歳 & 43 万人 & $13.4 \%$ & 108 万人 & $43.5 \%$ \\
$35 \sim 39$ 歳 & 36 万人 & $10.7 \%$ & 129 万人 & $50.8 \%$ \\
$40 \sim 44$ 歳 & 36 万人 & $8.8 \%$ & 186 万人 & $56.1 \%$ \\
\hline
\end{tabular}

総務省 労働力調査 長期時系列表 10

年齢階級別・雇用形態別雇用者数（5 歳階級）

示する。各内容の最後に非正規雇用の抱える問題点とと もに3，少子化対策に関する提言を行ら。

\section{| -1. 非正規雇用と結婚の現状と課題}

日本での結婚をめぐる動向は，少子化を考えるらえで も検討すべき課題のひとつである。現在の日本の婚姻率 は減少傾向にあり，生涯未婚率は上昇している。本節で は, 結婚に関する若い世代の状況, 結婚観や実際の婚姻 状況について，雇用形態による違いを報告する。

結婚さえすれば子供が生まれるわけではないが，婚姻 率の減少が少子化を促進し, また非正規雇用が結婚の障 害として働くなら, 非正規雇用者の増加している日本の 状況（表 1）を見直す必要があるだろら。な牧，少子化 社会を広く社会現象としてとらえれば，その後結婚しな かった単独世帯にも注目する必要がある。未婚男性や女 性については, 現状では, その雇用形態が非正規雇用で ある場合に今後の世帯所得の低さが課題になる可能性が あり, 将来, 低所得の独居高齢者の課題にも結びつく。 少子化社会の中で, 少ない労働力人口で高齢者を支える 今後約 50 年の日本社会を見据えた場合，今後増えゆく と推測される低所得の独居高齢者とその対策は喫緊の課 題である。

\section{I-2．結婚の機会と非正規雇用の関係}

\section{エビデンスその 1 : 日本の婚姻率と未婚率の現状}

現在の日本の婚姻率は減少傾向にある。第 2 次ベビー ブームであった 1970 年代前半の結婚件数は年間 100 万 組を超えており, 人口千人あたりの婚姻件数である婚姻 率も 10.0 を超えていた。乙かし, 人口の減少と婚姻の 減少に伴い，2015 年の年間婚姻件数は約 64 万組まで減 少し，婚姻率は 5.1 に留まっている (1)。このような婚 姻率の低下の背景には若年層の未婚率上昇と晚婚化があ ると考えられる。

未婚率を年齢階級別に調べると，2015 年の時点での $20 \sim 30$ 代（25-29 歳・30-34 歳・35-39 歳）の未婚率は, 男性は $72.7 \% ， 47.1 \% ， 35.0 \%$ ，女性は $61.3 \% ， 34.6 \%$, $23.9 \%$ であった。3 0 年前の 1985 年には同じ年齢層で男 性は $60.6 \% ， 28.2 \% ， 14.2 \%$ ，女性は $30.6 \% ， 10.4 \% ， 6.6 \%$
であったため, 特に男女共に 30 代, そして女性の 20 代 での未婚率が上昇していることがわかる（2）。さらに 50 歳の未婚割合と定義される生涯未婚率は, 男性で $23.4 \%$, 女性で $14.1 \%$ であり，平成に入ってから急増している。

こうした未婚率の増加とも関連し, 平均初婚年齢も 1970 年代以降高まって拈り, 晚婚化が進んでいる。 1975 年の平均初婚年齢は男性で 27.0 歳, 女性で 24.7 歳 であったのに対し，2015 年には男性で 31.1 歳，女性で 29.4 歳にあった。また, 第 1 子出生児の母親の平均年齢 は 2011 年にはじめて 30 歳を超え, 2015 年には平均 30.7 歳であった。

未婚化や晚婚化の理由として, 女性の就労や大学進学 といった社会への進出と経済的に不安定な若年層の増大 と共に, 必ずしも結婚する必要はないといら考光が増加 している背景も報告されている（3）。しかし，実際は若 い世代で結婚に対する希望が急減しているわけではな い。2015 年に $18 \sim 34$ 歳の未婚者を対象にした調査では, 「いずれ結婚するつもり」と答えた者の割合は，男性 $85.7 \%$ ，女性 $89.3 \%$ であり，約 30 年前（1987 年）で同様 に答えた男性 $91.8 \%$ ，女性 $92.8 \%$ と比へ，少なくなって いるとはいえ，まだ大多数が結婚願望を持っている(4)。

それでは，ぞのような要因によって若年層が結婚を控 えるのであろらか。主に公的統計をもとにその理由を検 討する。

\section{エビデンスその 2 : 結婚を妨げる理由 収入と不安定雇用}

18 歳から 35 歳未満で結婚願望がある未婚者に対し, 現在交際している人と（あるいは理想的な相手が見つ かった場合） 1 年以内に結婚するとしたら何か障害にな ることがあるかをたずねた調査では，男性の $68.3 \%$ ，女 性の $70.3 \%$ が結婚することに何らかの障害があると回 答していた。その障害として挙げられた最も多い理由は, 男性の $43.3 \%$ ，女性の $41.9 \%$ が選んだ「結婚資金につい て」である。その他の理由は「職業や仕事上の問題」（男 性 $14.5 \%$ ，女性 19.9\%） が多く，男性特有の理由として は「結婚のための住居」（男性 21.2\%）も挙げられた（4）。 厚生労働省では 2002 年以降に成年者に縦断調査を実 施して挆り，そのコホートに関する分析では，2000年 代に結婚した者としなかった者を分析した結果，20 代 での結婚を促した要因は, 収入が高いことであり, 他方, 学校卒業直後の就業がパート・アルバイトや無職である ことが婚姻を阻む要因と分析されて扣り（5)，所得や不 安定な身分での雇用を経験することが結婚と関連すると 報告されている。

\section{エビデンスその $3:$ 雇用形態と結婚}

所得や将来の不安と関連しらる雇用形態の違いについ て，実際の結婚状況を比較した調査がある。雇用形態の 詳細別に配偶者がいる割合を調べた結果，20〜24 歳の 男性で正社員 $8.6 \%$, 非典型雇用 $4.5 \%$ （らちパート・ア ルバイト $2.6 \%$ ), 無業 1.6\% であり, 30〜34 歳男性では, 
正社員 $57.8 \%$, 非典型雇用 $23.3 \%$ （うちパート・アルバ イト 13.6\%), 無業 10.2\% であった。特に 30 代の男性で 雇用形態による違いが婚姻と関連して抢り, 不安定な身 分である非正規雇用や無職の男性では結婚している割合 が低かった（6）。

\section{エビデンスその 4 : 雇用形態による結婚意欲のちがい}

そもそもの結婚意欲についても雇用形態による違いが あるといら結果が, 既出の厚生労働省の縦断調査で報告 されている(5)。独身者の結婚意欲を性別に調べると, 男性の場合，「結婚意欲あり」と回答するのは正規雇用 で 68.0\%，非正規雇用で $45.6 \%$ （正規雇用との差－22.4 ポイント）であり，反対に「結婚意欲なし」は正規雇用 で 8.3\%，非正規雇用で $20.4 \%$ (同差+12.1 ポイント) で あった。他方，女性では「結婚意欲あり」と回答したの は正規雇用の $79.3 \%$ ，非正規雇用の $61.8 \%$ （同差 -17.5 ポイント）であり，「結婚意欲なし」は正規雇用で 5.7\%, 非正規雇用で $12.7 \%$ (同差＋7 ポイント）であった（7）。 したがって，雇用形態による結婚意欲の差が男女ともに 認められ，とくにその差は男性で大きいといえる。結婚 意欲があっても結婚できない者, 結婚意欲がなくてもそ の後結婚する者もいるが, 概して, 結婚意欲がない者で の婚姻率は低いことが同調査で示されている。

同じ調査（5）を用いた詳細な分析からは，特に男性で は, 正規雇用から非正規雇用や無職になるといら変化が, 結婚意欲を有意に低下させる要因であった (5)。同調査 は結婚意欲の理由が不明であるが, 非正規雇用で正規雇 用と比べて結婚意欲が低いことは，結婚資金としての収 入や将来に対する不安, あるいは非正規雇用で仕事を掛 け持ちするなどの時間の不足が影響している可能性が考 えられる。

\section{エビデンスその 5：収入と結婚}

主に男性の結婚意欲の妨げになり得る収入は，実際に 婚姻率の違いももたらしている。30〜34 歳男性の年収 別配偶者保有割合では, 年収 250 万円未満の男性で配偶 者を有する者が $50 \%$ を下回るのに対し，800万円以上 の男性ではほぼ $90 \%$ と高い割合にあった（6)。

収入を規定するのは，勤続年数と共に，雇用形態と就 業する産業が関わっている。日本では正規雇用と非正規 雇用の収入の違いは大きく, 2016 年の調査では, 男性 は正社員・正職員（以下，正規雇用とする） 34.9 万円, 正規雇用以外 23.5 万円，女性では，正規雇用 26.2 万円， 正規雇用以外 18.9 万円となっている (8)。非正規雇用が 正規雇用と比べて収入の面で不利な状況は変わらない が，現在の差でも，統計を取り始めた 2005 年以降で過 去最少となって扣り, 今後の同一労働同一賃金の国の施 策の遂行状況によっては改善が期待される。

収入は産業別にも異なって抢り, 卸売・小売業, 宿泊・ 飲食サービス業などへの従事が保険・金融業などと比べ て収入が低い産業である。そして大企業と比べた場合の
中小企業での勤務も，特に 30 代以降 50 代に特いて男性 で賃金が低くなる傾向にある $(8)$ 。

このように，所得は雇用形態や産業，従事する事業所 の規模などに関連して扣り，その影響を受けて結婚や家 族形成に違いが生じている可能性が否めない。

\section{エビデンスその $6 ：$ 結婚相手に期待する条件}

結婚に際して男性が収入を気にする傾向は，女性が結 婚相手に期待する条件からも解釈できて, 男女のミス マッチがある。

結婚する希望を持つ未婚者が相手に求める条件は, $95 \%$ 以上の男女が「人柄」を支持するが，その活かの 理由については性差が見られる。男性にとっては「人 柄」の次に大事な条件は多い順に「育児・家事の能力 $(92.8 \%) 」 「$ 仕事への理解 $(88.2 \%) 」 「$ 容姿 $(84.3 \%) 」 て ゙$ あるのに対し，女性は「育児・家事の能力 $(96.0 \%) 」 「$ 経

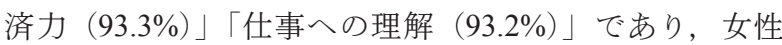
が男性に求める条件として「経済力」が果たす役割は大 きい（括弧内は重視する・考慮すると回答した割合）。 また，女性は男性より相手の職業や学歴を重視する傾向 にあり，相手の条件として「職業」を挙げるのは男性の 47.5\% に対して女性 $85.5 \%$ であり，「学歴」を上げるの は男性 30.5\% に対して女性 52.7\% であった（4）。

女性の結婚相手に期待する条件に男女の違いがあり, 特に女性の側の条件に経済力が入っていることは，男性 の年収が結婚を妨げる要因となる可能性がある。

\section{I -3. 非正規雇用と結婚における少子化対策への提言}

結婚については，相手と出会らことや本人の判断と いった，個人的な側面もあるが，結婚願望を持ちながら それがかなわない社会環境があるのだとしたら，それは 改善すべきである。なお，少子化との関連で「未婚」や 「非婚」を考える時，単純に子供が生じる可能性が減る だけではなく，社会における配偶関係の不存在による相 互扶助の可能性も減じることにも注意が必要である。今 回提示したエビデンスから，若年者を中心に婚姻率が低 下し未婚率が高くなっている現状とともに，結婚を阻む 理由として「結婚資金」や「職業や仕事」など，社会経 済上の身分があげられていた。実際に収入や雇用形態に よる婚姻の差が認められており，所得の高い者と比べて 低いもの，正規雇用者と比べて非正規雇用者では結婚し ている者の割合も結婚意欲も低かった。収入は雇用形態 や就業している産業や企業規模にも関連があることか ら，雇用にまつわる様々な要因が特に若年層の結婚に影 響を及ぼしている可能性は否めない。

政府が進める働き方改革などの施策のうち，特に非正 規雇用と正規雇用者の社会経済的な格差をなくす向きへ の動さが期待される。施策の評価として，国際労働機関 (ILO) で提案され，持続可能な開発目標の経済成長の 一環としても掲げられている「Decent work（働きがい 
のある人間らしい仕事）を全ての人へ」と言ら目標を見 据えた労㗢衛生に関する研究が必要であり，ワーク・ラ イフ・バランスを実現する条件への研究が必要である。 結婚に関していえば，日本に打いては有効なアウトカム として, 雇用形態や職業別に「結婚への希望とその実現・ 達成率」などを調査することが考兄られる。その結果, 若年層の婚姻や人生設計に括ける障害として, 社会経済 的な理由が減るよう期待する。

\section{II -1. 非正規雇用と妊娠・出産の現状と課題}

非正規雇用の増加は，わが国の子どもの出生にどのよ うな影響を及ぼしているであろらか。国立社会保障・人 口問題研究所による出生動向基本調査（1940 年～）に 扣ける夫婦の出生力に関する調査では, 「夫婦の平均理 想子ぞも数」,「平均予定子ぞも数」とも低下し過去最低 となっており（理想子ども数： 2.42 人（2012 年） $\rightarrow$ 2.32 人 $(2015$ 年), 予定子ぞも数 : $2.07 \rightarrow 2.01)$, 予定 子ども数が理想数を下回る理由としては「子育てや教育 に打金がかかりすぎる」(56.3\%) が最多となっている ことから，低所得で社会保障制度等の適用率が低い非正 規雇用は夫婦が積極的に子どもを望まない要因となる可 能性が考兄られ $れ$ 只。

\section{II -2. 非正規雇用における妊娠・出産に関する調査}

\section{エビデンスその $1:$ 雇用形態と出生力}

「夫婦が何人の子どもを持つか」はカップルの価值観 に関する問題であり，子を望んでも得られない事情（不 妊等）や社会通念の変化も絡んでくることから，夫婦の 出生力と雇用形態との関連を明らかにしらるデータは少 ないのが現状である。厚生労働省が 21 世紀成年者縦断
調査より集計した共働き夫婦の子ども数に関する調査で は，希望する子どもの数は男性・女性とも正社員である 場合が最も多く，男性・女性とも非正社員である場合に 最も少ない。実際の平均子ども数に扣いても，男性が正 規雇用の場合は 1.79 (妻が正規雇用) $~ 1.90$ 人（妻が非 正規雇用）であるが，非正規雇用では 1.09 (妻正規） 1.36 人（妻非正規）と差が生じていることから，雇用形 態は夫婦の出生力に大きく影響を及ぼすものと推察され る(10)。

従来わが国の女性労働者は，結婚後家事や子育てに備 え退職するのが一般的であったが，現在では妊娠・出産 後も就労を継続する労働者が主流となっている。「子ぞ もを持つ予定のある妻」に限定した調査でも就業率は $77.7 \%$ （自営業含む）に達しており，正規雇用者の割合 が 1970 年代以降 30 ～40\% 前後で推移しているのに対 し，パート・派遣等の非正規雇用者の割合は同時期に $9.2 \%$ から $34.2 \%$ に増加している（9）（図 1)。労働力活 用の観点から出産・育児期の女性労働者への支援の重要 性が増しているが，女性労働者の 56\%(11) を占める非 正規雇用者へのサポートは種々のレベルで正規雇用者と は格差がみられている。

\section{エビデンスその 2 : 非正規雇用者における産休・育休制 度の利用}

産前産後休業（いわゆる産休）制度は，労働基準法に より雇用形態を問わずすべての女性労働者に適用され， 妊娠・出産を理由とする解雇・雇い止めは男女雇用機会 均等法により禁止されている。これらにより，育児休業 の対象から外れる非正規雇用者でも産休のみで復職して 就業継続することは法的には可能である。また，2005 年施行の改正育児・介護休業法により，有期契約のパー ト・契約・派遣等であっても一定の要件を満たす場合注 1)

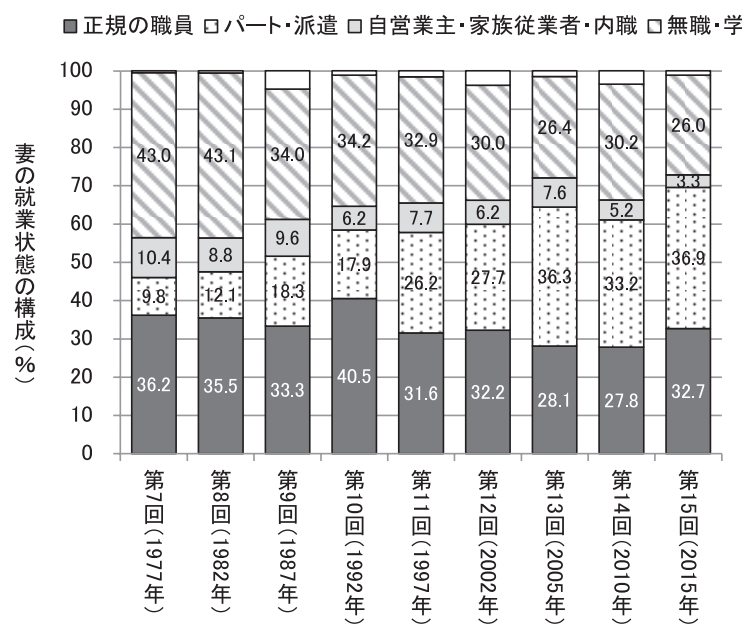

総数

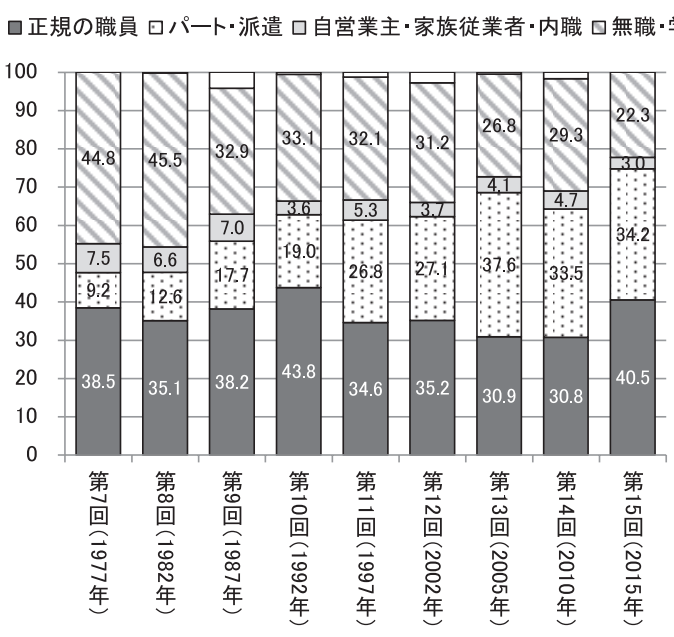

（再掲）子どもを持つ予定あり

図 1 子供のいない妻の就業状態の構成（文献 9 より引用） 


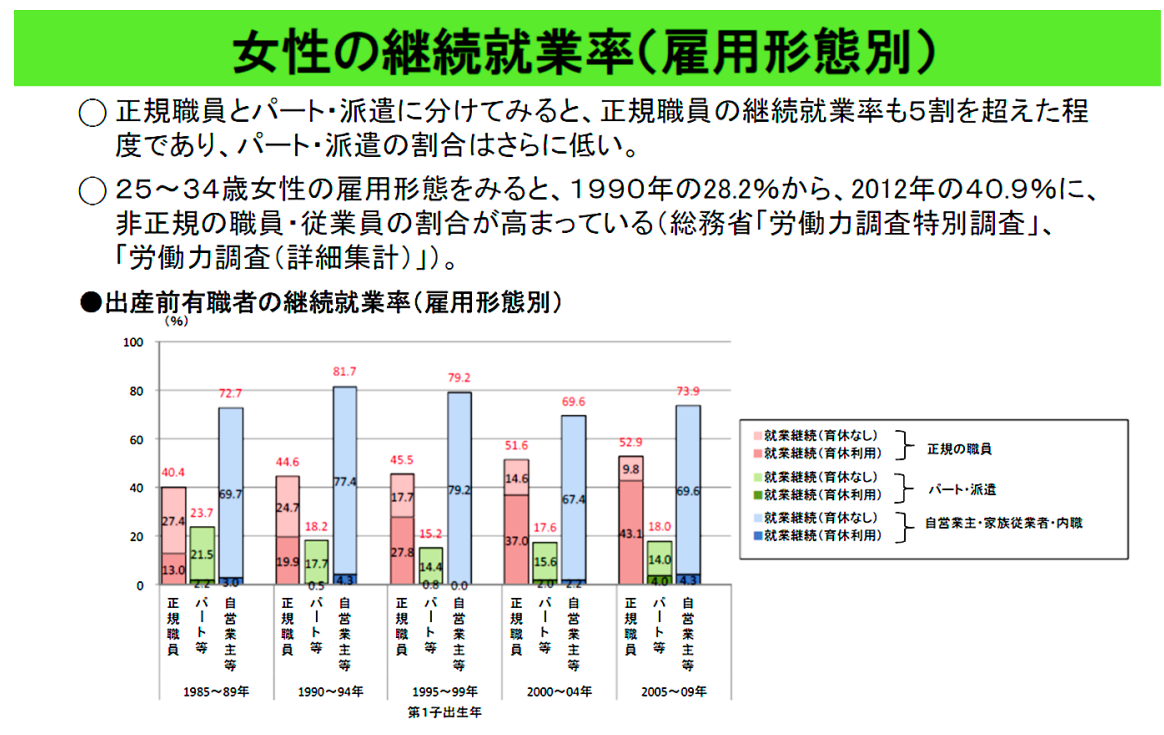

図 2 出産前有職者の継続就業率（雇用形態別）（文献 12 より引用）

は育児休業（育休）の対象と明記されている。（注 1： 2017 年 1 月の改正では, 1 歳に満たない子を養育する男 女労働者で「同一の事業主に引き続き 1 年以上雇用され, 子が 1 歳 6 か月になる日の前日までに労働契約の期間が 満了することが明らかでない場合」に適用される)。こ らした法整備により有期契約労働者の育休後の職場復帰 者の増加が期待されたが, 法改正後（2005～2009年） に扔いても，正規雇用者で育休を利用した女性の継続就 業率が $43.1 \%$ であるのに対し，パート・派遣等で育休 を利用した労働者の継続就業率はわずか $4 \%$ であり，育 休なしと合わせた場合でも $18 \%$ と 2005 年以前と同水準 にとどまっている（図 2）（12）。

非正規雇用者の継続就労が困難な要因には, 育休取得 の適用条件が㛜しく妊娠・出産時期によっては適用外と なりやすいことがあげられるが, 非正規社員の育休制度 についての認知度が低いことも問題とされている。例え ば, 妊娠経験のある有期契約労働者（20〜 50 歳, 158 名） に実施した民間調査 (13) によると, 非正規でも一定条 件を満たせば育休を取れることを知らなかった者は $33.3 \%$ 打り，その理由（複数回答）としては「そのよう

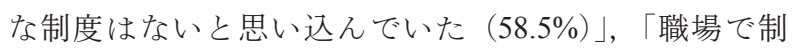

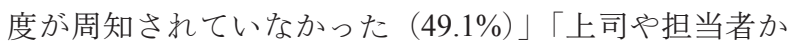

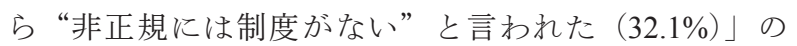
順で多かった。また育休制度を知っていた者のらち，実 際には育休を取得しなかった割合は $55.2 \%$ であり，そ の理由は「産休すら取らせてもらえず育休までたどり着

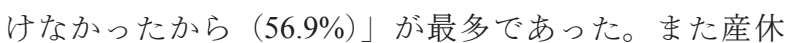
に関しては，72.8\%の女性が非正規でも産休を取得でき ることは知っていたが，そのうち $44.3 \%$ が取得してお らず，理由としては「上司や担当者から仕事を辞めるよ ら促されるマタハラ（マタニティー・ハラスメント）を 受けて辞めた，もしくは雇い止めされたから」が $54.9 \%$
と最多であった。一方, 企業の経営者や管理職（212 名） に実施した同調査では，「非正規社員には育休がないと 思う」と答えたのは $24.5 \%$ おり，「産休がないと思う」 と回答した割合も $22.2 \%$ に上っていた。本調査は八ラ スメント防止の観点から実施されたことによるバイアス が含まれる可能性はあるものの, 産休・育休制度に対す る職場での周知不足や雇い止めを恐れて権利を主張でき ない就労環境が，非正規雇用者の出生力の低下や継続就 労からの離脱を招いている可能性が考えられる。

\section{エビデンスその 3 : 非正規雇用者における産休・育休時 の収入確保について}

前の部分では，出産と育児に際した雇用継続の安定性 から休業制度と利用状況を述べたが，もら一つ，労働者 にとって重要事項である休業中の所得保障の状況を考え たい。就労女性が産休を取得する場合, 健康保険から出 産育児一時金（いわゆる分娩にかかる費用相当）が給付 される他, 出産手当金として標準報酬月額の 3 分の 2 が 支給されるのが通常である。しかし，加入している健康 保険が国民健康保険である場合は出産手当金のような所 得保障は適用されない。もちろん，健康保険に「被保険 者」として加入していない場合，すなわち配偶者や家族 などの被保険者の「被扶養者」である場合，出産育児一 時金は給付されるが，所得保障としての出産手当金はな い。多くの非正規雇用者は，家族の被扶養者として被用 者健康保険を利用しているか，もしくは国民健康保険に 加入しているのが現状ではないだろらか。

雇用者自身がいわゆる被用者健康保険に被保険者とし て加入するためには, (1)従業員 501 人以上の事業所で週 20 時間以上働くか, (2)事業所規模に関わらず週に 30 時 間以上働く，もしくは，(3)従業員が少なくても被用者健 康保険を用意しかつ労働時間に関わらず加入を認めてく 
れるよらな事業所で働く, のいずれかに該当する必要が ある。これらのらち, 前述(1)は最近(2016年 10 月)になっ て加わった加入要件の緩和であるが, この条件で新規に 健康保険加入の対象となるのは 25 万人程度で，これは 非正規雇用者約 900 万人中の $3 \%$ 未満にしかならない (14)。いずれにせよ非正規雇用者が被用者健康保険へ加 入するのは狭き門であり，それ以外の非正規雇用者では 出産前後に仕事を休むことはすなわち無収入になること を示している。

いっぽう，産休期間が過ぎて育休期間に突入した場合 の所得は雇用保険により保障される。その場合もやはり 最高で月額所得の 3 分の 2 が支給されるが, (1)雇用保険 の加入期間が 1 年以上であることが支給要件となる。そ もそも雇用保険加入者の対象となるには(2)週 20 時間以 上かつ 31 日以上雇用が見込まれることが要件で, 健康 保険の加入条件注ど厳しくはない。実際, 全雇用者に占 める雇用保険加入率はこちらも要件が緩和された 2010 年以降やや増加して 7 割を超えているため, 多くの非正 規雇用者も加入していると思われる（14）。しかし，実 際に支給されるためにはさらに, (3)育休後に同雇用先で 就業を再開することと, (4)子供が 1 歳 6 か月（18 か月） までの間に労働契約が更新されないことが明らかでない こと, が要件となっている。つまり, 育児休㗇が開始さ れる 1 年（12 か月）前までに雇用保険へ加入できる条 件で雇用契約を結び, さらに出産から 18 か月以上は雇 用が継続されることが必要である。

妊娠期間が 10 か月，産後に育児休暇を開始するまで 2 か月あるとして, 非正規雇用者が出産を契機に無収入 になりたくなければ, 非正規雇用でも被用者健康保険に 加入できる会社を探し, 最低でも 2 年 4 か月以上の有期 雇用を結び，健康保険と雇用保険にも加入できるよう労 働時間を保つと言う条件をそろえて, すぐさま妊娠すべ きであろう。しかし, 就労開始直後に狙って妊娠するこ とや雇用契約期間の約半分以上を休業することに対する 社会心理的抵抗もあろらし, そもそも上記の 3 条件を満 たすことは容易ではない。また父親となる男性もまた 非正規雇用であれば妊娠出産が世帯に及ぼす経済りスク はさらに大きくなる。非正規雇用者が子供を望んでも実 行に移さないのはこのような経済不安が背景にあると思 われる。

\section{II -3. 非正規雇用と妊娠・出産における 少子化対策への提言}

雇用形態と希望する子供の数の関係は，夫婦が両者と も正規雇用である場合が最も高く，近年は妊娠出産後も 就業を継続する女性が増加しているため, 雇用身分にか かわらず，妊娠や出産をサポートするような労働現場で の制度が必要である。しかし, 出産育児に関わる休業制 度の周知や所得保障制度の利用条件は正規雇用者を中心 にデザインされている点が課題である。
非正規雇用が拡大寸る中でも出産育児を行ら女性が増 えるためには，産休・育休制度をはじめとする子育て支 援対策を正規雇用との違いを考慮して行い，安定した就 業継続が可能になるための課題を明らかにしていくこと が重要である。また，産休・育休期間の所得保障をまか なら被用者保険の適用範囲をさらに緩和し，多くの非正 規雇用者が経済不安の無い状態で妊娠・出産の機会を選 択できるよらに検討していくべきである。また，出産や 妊娠に関わる制度の労働現場での周知について，職場で の教育や情報共有のあり方に関寸る研究や，被用者保険 制度の改正において, 適用対象となる雇用者割合の適切 な試算・評価に関する研究が今後必要と思われる。

\section{III-1．非正規雇用と育児の現状と課題}

非正規雇用は子の養育に際しても，経済的および情緒 的 (時間的) な条件が整わず困難が生じやすいと言える。 養育世帯が非正規雇用で成り立ち経済的に恵まれない と, 育児に際して十分投資できない。投資の帰結として, 教育期間が短くなる傾向があり，その場合は非正規雇用 に就く傾向がある。非正規雇用になると, 前述したよう に，婚姻や出産の機会に際し社会的条件や経済的条件が 整いにくく，希望しても子供をその数だけ持たない傾向 がある。非正規雇用が次世代育成に困難を伴らのならば, 同時に少子化を促進する連鎖の問題も生じると言えよう。

\section{III -2．非正規雇用と育児上の困難に関する情報}

\section{エビデンスその $1 ：$ 子の養育に必要な費用と非正規雇用 との関係}

子の養育には, とにかく費用と手間（時間）が掛かる。 養育費用を，非正規雇用による所得収入だけで賄らと不 十分な場合が多い。先に述べたように，正規雇用以外の 男性の収入は正規雇用者の $67 \%$ 程度 (23.5 万円/月), 女性では 72\%（18.9万円）（8）である。非正規雇用の経 済的な特徵として, 時間当たりの給与の少なさや, 就業 継続の不安定さ，そして社会保障の保険料負担が大きい こと（企業負担が付く（個人負担の減る）被用者保険へ 加入できない場合が多い)，の3 点が挙げられる。非正 規雇用者の 1 時間当たり所定内給与額は勤続 $5 \sim 9$ 年で, 男性で 1,184 円，女性の場合は 1,062 円程度である。一 般労働者は男性 1,654 円，女子約 1,416 円，そしてその 他に賞与や特別給与が数十万円支給される(8)。も乙給 与を増やしたければ長時間就労しなければならない。し かし，一方で長時間の就労は子の養育に十分な時間を割 けないことを意味する。

また，子供の発達や成長度合いを測る指標として学力 の評価が用いられるが，親の経済力と子供の学力が関連 する研究報告もある (15)。この研究では親の学歴や職 業についても分析しているが，結局，子供の学力を説明 する要因として通塾の有無，教育費支出，世帯所得など 
の経済要因がより強い説明力を持つと示した。この研究 で, 親の雇用形態々のものは検討していないが, 非正規 雇用は低い所得と関連を示すため, 通塾や教育費支出と 関連し，子供の学力へも影響することが予想される。

\section{エビデンスその 2 : 非正規雇用と健康保険}

非正規雇用の養育上の問題は低所得だけではない。保 険料負担率の高い公的社会保険である国民健康保険等へ の加入が躊躇され, 無保険になることも指摘されている。 国民健康保険の被保険世帯でありながら保険料を滞納し ている世帯は 18.4\%（約 382 万世帯）にも上ると報告さ れている (16)。長期間滞納は無保険状態を意味するが, 子どもがいる世帯だけでも 33 万世帯が相当し，ここに は乳幼児 5,522 人を含む 3 万 2,776 人もの中学生以下の 子どもが含まれる (16)。無保険状態になる要因として は, 世帯の所得状況や本人の就業状況が影響することが 既に実証されて扣り (17), 収入が低く就業継続が不安 定である非正規雇用が関連していることは言らまでもな い。家族構成や被扶養者の人数に関わらず保険料の設定 がなされている被用者保険と異なり, 国民健康保険は被 保険者数に応じて保険料が課せられているため, 非正規 雇用世帯で被扶養者, すなわち子ぞもが居る場合は保険 料が高額になり支払いが困難である。この状況を受け， 2016 年より被用者保険の適用条件を「週 30 時間以上の 労働時間」から「週 20 時間以上, 年収 106 万円以上, 勤務期間 1 年以上見込久」の短時間労働者まで拡大した。 こうした非正規雇用世帯の増加に対応した社会保険の仕 組みの改変は望ましく, 今後も情勢変化に対応していく ことを期待したい。

医療保険へ加入していても，実際に医療機関を利用す る際には空口で自己負担が生じる。近年は多くの自治体 で就学前の子供の医療費に関する自己負担を軽減もしく は無料化しているが, 所得 5 分位ごとの入院や通院状況 を分析した研究からは, 喘息を除き, 湿疹などの慢性疾 患に関する通院は, 貧困層に扣いて有意に低く, 健康問 題があっても受診・受療控えが行動として生じる可能性 が報告されている（18）。貧困と非正規雇用の関連は既 に指摘されて抢り, 日本では, 非正規雇用者からなる世 帯は，失業や無業世帯に比べて貧困率が高いことも 2000 年代に観察されており (19), 非正規雇用世帯に拉 汀る供の健康維持・管理が十分ではない可能性がある。

\section{エビデンスその 3 : 子の養育に必要な時間（手間）と非 正規雇用}

家事や育児は便利な家電の利用や既加工食品の購入に よってある程度の時間を短縮できるが，特に人的なケア の部分は代替が効きにくい $(20)$ 。人的ケアの部分をへ ルパーやナニ一などで外注すると費用が高くつくため, 経済格差の比較的小さい現在の日本国内では現実的では ない。人的ヶアは, 大量生産できる家電や生活用品, 食 品とは異なり, 各家庭や子供の状態など個別のニーズに
合わせて用意する必要があり，価格が下がりにくいため である。

子の養育を複数人で行らよらな家族形態であれば少な くとも養育に必要な手間や時間は分散され，養育者一人 当たりの負担は減る。農林漁業や家内工業や商業が主な 産業であった時代には, 生活と経済生産が同場所（家庭） で行われて扣り，養育者が世帯内に複数いたため手間や 時間は分散されていた。戦後の高度経済成長期（昭和中 頃）に促進された性別分業世帯（多くは男性雇用者と無 業の妻から成る世帯）では，子の養育に必要な手間や時 間を世帯内の養育者で分散せず，家庭内で一人（専業主 婦と呼ばれる女性）が分担するようになった。しかし， 2016 年には性別分業世帯は 664 万世帯へと減少し, 一 万で夫婦共働世帯は 1,129 万世帯へと増加している(21) ように，今日，また性別分業世帯も1990 年代半ばを境 に一般的ではなくなっており, 養育者は同時に家庭外で 就業もするようになってきている。

では，夫婦共働き世帯に打ける 2 人程度の就労者が同 様に養育も分担しているかと言うと, 年齢別女性就業率 の $\mathrm{M}$ 字カーブが示すよらに養育の時間や手間が代替さ れにくい時期は相変わらず女性が就業を中止している実 情がらかがえる。一旦離職して育児を担らと, その後も 引き続き就業と両立させるべく，短時間労働等の非正規 雇用につく傾向がある。男女雇用機会均等法等の法律に より，女性の就労は促進されたと考えられるが，実際に 女性雇用者の半数以上（約 $57.5 \%$ ） はパート，アルバイ 卜, 派遣社員など就労時間の短い非正規雇用である (22)。出産や育児に際して出産休层や育児休業の制度が 整った正規雇用に就きやすい大卒・大学院卒の女性で あっても, 離職理由に育児を挙げる者は $18.2 \%$ もいて, 同学歴の男性離職者が育児理由を $0.1 \%$ しか挙げていな いことと対照的である (23)。別の研究では, 男性は妻 が就労していても，もしくは自身の収入が何らかの事情 で減っても家事育児へ時間を割かないことが調査から示 されている (24)。このため, 夫婦共働世帯において育 児の負担偏重に苦しむ女性の存在が予想されており，本 邦でも性別分業をしている専業主婦の健康指標は高く, 仕事と家庭の両負担のある就労女性の健康指標が低いこ とが既に示されている(25)。

なお，近年の不況等により若年世代において男女とも に非正規雇用化が進み $25 \sim 34$ 歳の雇用者の約 3 割を占 めるようになっている（表 1)。この実情は，世帯内で 非正規雇用者しかいない，いわゆる非正規雇用世帯が一 定の割合で存在し，かつ増えていることを示している。 非正規雇用の労働条件は先に述べたように時間単位の収 入が低く, 就業継続が不安定で, 社会保障も充実してい ないため, 非正規雇用世帯の養育者が安心して就労以外 の時間を子の養育時間に充てられるかは疑問である。子 を養育する 30 歳前後の年齢集団に拈ける「不本意」非 正規者の割合は高く（男性 $48 \%$ ，女性 $22 \%$ ），男性の場 合はその後 50 歳代半ばまで $50 \%$ を継続し，二人に一人 
表 2 ひとり親家庭の現状（就業状況）

\begin{tabular}{|c|c|c|c|c|}
\hline & & 母子世帯 & 父子世帯 & 一般世帯 \\
\hline \multicolumn{2}{|l|}{ 全世帯数 } & 123.9 万世帯 & 22.3 万世帯 & 1,768 世帯 \\
\hline \multicolumn{2}{|c|}{$\begin{array}{l}18 \text { 歳未満（児童）のいる } \\
\text { 世帯数 }\end{array}$} & $\begin{array}{l}\text { (母子のみ)* } \\
82.1 \text { 万世帯 }\end{array}$ & $\begin{array}{l}\text { (父子のみ)* } \\
9.1 \text { 万世帯 }\end{array}$ & $\begin{array}{c}\text { (児童のいる世帯) } \\
\text { 1,209 万世帯 }\end{array}$ \\
\hline \multicolumn{2}{|l|}{ 就業率 } & $80.6 \%$ & $91.3 \%$ & $\begin{array}{l}\text { 女性 } 64.4 \% \\
\text { 男性 } 81.6 \%\end{array}$ \\
\hline \multirow{2}{*}{ （雇用者のらち） } & 正規 & $43.0 \%$ & $87.1 \%$ & $\begin{array}{l}\text { 女性 } 45.6 \% \\
\text { 男性 } 80.1 \%\end{array}$ \\
\hline & 非正規 & $57.0 \%$ & $12.9 \%$ & $\begin{array}{l}\text { 女性 } 54.4 \% \\
\text { 男性 } 19.9 \%\end{array}$ \\
\hline \multirow[t]{3}{*}{ 平均年間就労収入 } & & 181 万円 & 360 万円 & \multirow{3}{*}{$\begin{array}{l}\text { 平均給与所得 } \\
\text { 女性 } 269 \text { 万円 } \\
\text { 男性 } 507 \text { 万円 }\end{array}$} \\
\hline & 正規 & 270 万円 & 426 万円 & \\
\hline & 非正規 & 125 万円 & 175 万円 & \\
\hline
\end{tabular}

*母子または父子以外の同居者が居ない

(出典) 母子世帯・父子世帯は 2011 年度全国母子世帯等調査, 一般世帯は 2014 年労働力調査, 2010 年分民間給与実態統計調査（著者により文献 23 より再集計）

が就業へ不満足を示している $(26)$ 。非正規雇用による 就労不本意・生活不満足と, 育児負担感との関連は十分 実証されていないが，関連する可能性は否定できない。

\section{エビデンスその 4：ひとり親世帯の抱える問題}

子の養育を単独で担ら世帯（ひとり親世帯）も増加し てきている。国民生活基礎調査のデータ等を基にした分 析よると (27)，今から 20 年以上前は児童のいる世帯を 分母としてひとり親世帯は約 4.0\%であったが（1988 年 度)，2011 年度には $7.6 \%$ へ増加している。非正規雇 用との関係で述べると，男性ひとり親の非正規雇用率は 13\% と一般世帯に比べてむしろ低い（表 2)。しかし， 女性ひとり親は $57 \%$ が非正規雇用でわずかに高い（表 2)。一般世帯の女性就業率が $64 \%$ であるのに対して, 女性ひとり親世帯の就業率は高く $81 \%$ であるが，その 多くが非正規雇用者であることが分かる。よって，女性 ひとり親世帯の平均収入は, 一般世帯の女性収入に比べ てかなり低い。その状態で子供を養育するのだから経済 的にはかなりの困窮がらかがわれる。母子世帯に限らな いが，ひとり親家庭の相対貧困率は $54.6 \%$ で，2 世帯の らち 1 世帯は貧困である (27)。

父子世帯は一般世帯に比べて非正規雇用率は低いにも かかわらず平均就労収入は低い。扣そらく男性就労者も また, 子どもを養育する手間や時間を得ることが必要で, 収入が増えるよう長時間労働をするのが難しいためかと 考兄らる。よって，この状況は養育者の性別にかかわ らず，単独養育者特有に起きる現象かと思われる。ひと り親家庭は経済活動と育児時間の負担をたった一人で請 け負い，双方の負担リスクが相互にトレードオフする関 係にあるため特に育児負担から来る困難が生じやすいた めである。

児童虐待件数の非常に高い米国に抢ける研究では，家 庭収入と览童虐待の関連が報告されており, 収入が貧困
ライン以下の家庭では児童虐待死亡数が飛躍的に高くな る (28)。日本でも東京都福祉局の調査で，児童相談所 が児童虐待のケースであると判断したらちの $31.8 \%$ が ひとり親家庭であり，続いて $30.8 \%$ が経済的困難を抱え る家庭であるとの特徵を報告している(29)。子供の虐 待死に関する家庭状況分析によると，実父の約 3 割が無 職またはパート勤務であったとの報告もある（30）。ひ とり親家庭に扣いて，もし非正規雇用故の経済的な困窮 がある場合は, 虐待の発生リスクが高まる可能性がある。

児童虐待などは，そもそも養育者の社会的排除も一因 とされる。非正規雇用者は健康維持管理活動の一助とも なる職域健康診断の対象者になりにくく，また機会も提 供されにくく(31), 能力開発や事故防止の機会となる 企業の教育訓練機会が低い等の状況がある(32)。職場 での意思決定過程への参加機会も少なく疎外感など社会 心理的影響や (33)，相対的経済格差が場を共有する者 全体の健康状態を損なら関連性など（34），社会的な孤 立を深めやすい。

な拉, 養育者が健康不良を理由に就業不可能となれば, 代替就労者がいないひとり親家庭は生活保護を受けるこ とになる。実際に生活保護受給率は母子家庭 $14.4 \%$ ，父 子家庭 $8.0 \%$ と全世帯平均が $3.2 \%$ であるのに比してか なり高い。生活保護を受給する場合，子供の大学進学に より「世帯分離」が行われ，保護費が減額される仕組み があるため，経済的な事情により進学をあきらめる傾向 がある。実際にひとり親家庭の大学進学率は $23.9 \%$ と， 全世帯平均 $(53.7 \%)$ の半分以下である。結果として, 子供もまた条件の悪い非正規雇用につく可能性が高く, 困難な状況が次世代へと連鎖していくことになる。

\section{III -3．非正規雇用と育児における少子化対策への提言}

現在の日本の就業構造は，経済生産の場と生活・育児 


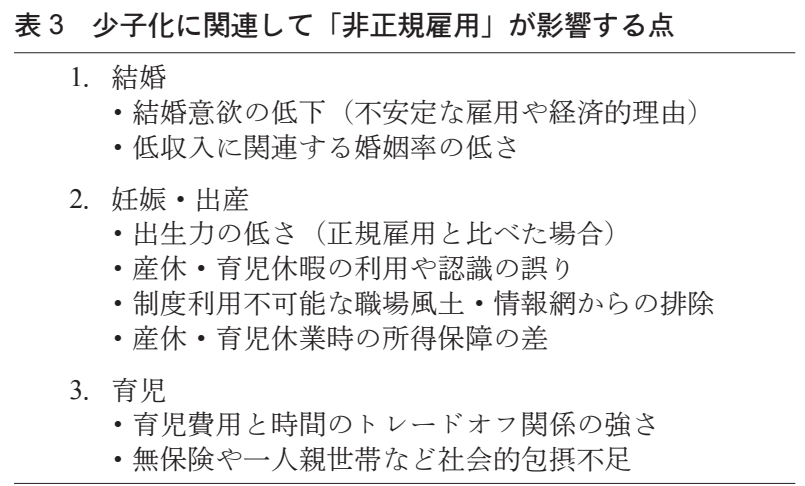

の場が切り離されている。本邦は性別分業を前提として, 長時間労働や非正規雇用による家計補助的な賃金・社会 保障等の制度を進めてきた。しかし，育児に費用がかか ることもあり, 分業では収まらず就労を試みる養育者は 多く, 就労と育児を同時に負担する養育者や，両者を世 帯内で単独負担する養育者が増加している。こうした養 育者の抱える育览上の困難，例えば養育に必要な費用が 不足する問題や，養育に十分な時間をかけられない問題 などは, 現状の労働条件や社会保障制度で十分対応でき て打らず，少子化を促進している可能性がある。保育園 の整備などに力を入れるのはもちろんであるが, 養育は 未就学時に限らず，今日は高校や大学などの高等教育の 時期まで継続する。特に, 高等教育を継続する上での経 済面の負担も大きいため, 非正規雇用による次世代育成 の困難を世代間連鎖させないためにも，非正規雇用を含 めた労働者全体の経済状態と生活時間との両者に十分配 慮した政策が少子化対策には必要だと思われる。

\section{まとめ：非正規雇用と少子化に関する提言}

少子化に結びつく要因として, 結婚・妊娠と出産・育 児について非正規雇用では不利な状況が複数示された (表 3)。

結婚の決断には価值観や好みなど個人的な側面も大き いが，収入や雇用形態など社会経済状況による婚姻の差 が認められて抢り, 非正規雇用者では結婚している者の 割合も結婚意欲も低いため, 雇用による社会経済格差を 解消寸る施策が必要であろう。若年層を中心に非正規雇 用が拡大している実情があり, 出産を行う若い女性のた めには，産休・育休制度の利用機会を増やし，これら休 業期間の所得保障を扣こなら被用者保険の適用範囲をさ らに緩和し，多くの非正規雇用者がカバーされるよらに 検討していくべきである。出産後 10 数年続く育児期間 に扣いては，養育費用に加党，情緒的・物理的時間が必 要であるが，個人の責任や努力にゆだねた状態で負担す るには困難を極める。性別分業を前提として, 養育者の 一人に長時間労働を課したり, 就業と育児の両負担を一 人の養育者に課したりことで健康上問題が生じる。特に, 養育に際して高等教育の経済面の負担は大きく, 高等教
育がなければ再び非正規雇用を生み出すことになる。非 正規雇用による次世代出産や育成の困難を世代間連鎖さ せないためにも，非正規雇用を含めた労働者全体に対し て，その経済状態と生活時間との両者に十分配慮した政 策が少子化対策には必要だと思われる。

今後期待される研究として以下が考えられる。まず, 少子化と雇用者の生活全般を考慮する上で, 結婚や妊娠・ 出産, 育児のライフコースについても,「Decent work（働 きがいのある人間らしい仕事）を全ての人へ」と言ら国 際的な持続可能な開発目標を見据えた労働衛生に関する 研究が必要である。例えば, ワーク・ライフ・バランス を達成する本邦に打ける有効なアウトカムとして「結婚 への希望とその実現・達成率」などを雇用形態や職業別 に調査し評価する研究などが考えられる。また，職場内 人間関係から排除されやすい非正規雇用者と出産や妊娠 に関わる制度について, 認知度の変化や周知, 職場教育 や情報共有のあり方に関する研究も必要であろら。さら に経済学的視点からの研究としては，被用者保険制度の 改正に対して，対象となる者の労働者全体に占める割合 とその効果, 拈よび子育てに掛かる時間と費用について, 労働時間や収入との関連性を試算・評価寸る研究も必要 と思われる。

利益相反なし

\section{文献}

（1）厚生労働省. 平成 28 年人口動態統計月報年計 (概数)の 概況. http://www.mhlw.go.jp/toukei/saikin/hw/jinkou/geppo/ nengai16/index.html (2017.10.05)

（2）内閣府. 平成 29 年版少子化社会対策白書 第 1 部 少子化対策の現状 第 1 章 少子化をめぐる現状 2 婚姻・出産の状況.

（3）厚生労働省. 平成 25 年厚生労働白書 第 1 部 若者 の意識を探る 第 2 章 多様化するライフコース 第 2 節 結婚に関する意識. http://www.mhlw.go.jp/wp/ hakusyo/kousei/13/d1/1-02-2.pdf (2017.10.05)

（4）国立社会保障 - 人口問題研究所. 第 15 回出生動向調 査（結婚と出産に関する全国調査（独身者調査））. 2015. http://www.ipss.go.jp/site-ad/index_Japanese/ shussho-index.html (2017.10.05)

（5）厚生労働省．21 世紀出生児縦断調査及び 21 世紀成年 者縦断調查特別報告書 (10 年分のデータより). http:// www.mhlw.go.jp/toukei/saikin/hw/judan/tokubetsu13/ index.html (2017.10.05)

（6）労働政策研究・研修機構. 資料シリーズNo. 144 若 年者の就業状沉・キャリア・職業能力開発の現状 平 成 24 年版「就業構造基本調査」より.2014. http:// www.jil.go.jp/institute/siryo/2014/144.html (2017.10.05)

（7）厚生労働省．21 世紀成年者縦断調査（平成 24 年成年 者）第 4 回 結果の概要. http://www.mhlw.go.jp/toukei/ saikin/hw/judan/seinen17/index.html (2017.10.05)

（8）厚生労働省. 平成 28 年賃金構造基本統計調査 結果の 概況. http://www.mhlw.go.jp/toukei/itiran/roudou/chingin/ 
kouzou/z2016/index.html (2017.10.05)

（9）国立社会保障-人口問題研究所. 第 15 回出生動向基本 調査. 2015. http://www.ipss.go.jp/ps-doukou/j/doukou15/ doukou15_gaiyo.asp (2017.10.05)

（10）厚生労働省. 平成 24 年版 労働経済の分析第 2 章 第 1 節 非正規雇用者，貧困・格差の現状，背景その 問題点, 対策. 2012, 134-135.

（11）総務省統計局. 労働力調査 平成 29 年（2017 年） 1 ～ 3 月期平均（速報）。 2017 年 5 月 9 日公表. http:// www.stat.go.jp/data/roudou/sokuhou/4hanki/dt/pdf/2017 1 . pdf (2017.10.05)

（12）内閣府.「第 1 子出産前後の女性の継続就業率」の動 向関連データ集. wwwa.cao.go.jp/wlb/government/top/ hyouka/k_39/pdf/ss1.pdf (2017.10.05)

（13）マタニティハラスメント対策ネットワーク. 非正規マ タハラ白書 非正規（有期雇用契約）で働きながら妊 娠した経験のある女性を対象にしたアンケート調査. 2015 年 11 月 発表. http://www.mataharanet.org/about/ whitepaper/ (2017.10.05)

（14）厚生労働省. 短時間労働者に対する被用者保険の適 用拡大. 第 89 回社会保障審議会医療保険部会資 料. 2015 年 10 月 2 日. http://www.mhlw.go.jp/file/05Shingikai-12601000-Seisakutoukatsukan-Sanjikanshitsu_ Shakaihoshoutantou/0000099460.pdf (2017.10.05)

（15）耳塚寛明. 学力格差は今や社会問題だ. エコノミスト 2007 年 1 月 23 日号

（16）厚生労働省.「資格証明書の発行に関する調査」の結果 等について (発表資料). 2008 年 10 月 30 日. http:// www.mhlw.go.jp/houdou/2008/10/h1030-2.html (2017.10. 05)

（17）湯田道生. 国民年金 - 国民健康保険未加入者の計量分 析. 経済研究 2006;57(4):344-356.

（18）阿部 綾. 子供の健康格差の要因一過去の健康悪化の 回復力に違いはあるか一。医療と社会 2013;22(3):255269.

（19）樋口美雄, 石井加代子, 佐藤一磨. 貧困と就業一 ワーキングプア解消に向けた有効策の検討. RIETI Discussion Paper Series 2011;11-J-056:1-21.

（20）筒井淳也. 仕事と家族：日本はなぜ働きづらく，産み にくいのか. 中公新書, 2015 .

（21）内閣府男女共同参画局. 男女共同参画白書平成 26 年 版 第 2 章 第 1 節 就業をめぐる状況. http://www. gender.go.jp/about_danjo/whitepaper/h26/zentai/html/ honpen/b1_s02_01.html (2017.10.05)

（22）厚生労働省. H24 就業構造基本調査 結果の概要（3. 雇用者（1）雇用形態）。2013，13-20 http://www.stat. go.jp/data/shugyou/2012/pdf/kgaiyou.pdf (2017.10.05)

（23）厚生労働省雇用均等 - 児童家庭局. 平成 20 年版 働く 女性の実情（雇用均等・児童家庭局一般資料 No. 1) 2009, 52-53

(24）筒井淳也, 竹内麻貴. 家事分担研究の課題 : 公平の視 点から効果の視点へ. 季刊家計経済研究 2016;109:1325.

(25) Nishikitani M, Nakao M, Tsurugano S, Yano E. The possible absence of a healthy-worker effect: a cross-sectional survey among educated Japanese women. BMJ Open 2012; 2(5): e000958 (1-10).

（26）厚生労働省職業安定局．非正規雇用対策・若者雇用対 策について（資料 9)（資料出所）総務省「労働力調 查（詳細集計）」(平成 25 年平均). www8.cao.go.jp/ shoushi/shoushika/meeting/taikou/k_2/pdf/s9-1.pdf (2017.10.05)

（27）厚生労働省. 2015 年一人親家庭等の現状について (資料 3). http://www.mhlw.go.jp/file/06-Seisakujouhou11900000-Koyoukintoujidoukateikyoku/0000083324.pdf (2017.10.05)

(28) Lindsey D. The welfare of Children. USA; Oxford University Press, 2013.

（29）東京都福祉局. 児童虐待の実態 II. 2005 年 12 月.

（30）社会保障審議会児童部会. 児童虐待要保護事例の検証 に関する専門委員会 第 2 次報告. 2006. http://www. mhlw.go.jp/houdou/2006/03/h0330-4.html

(31) Inoue M, Tsurugano S, Nishikitani M, Yano E. Full-time workers with precarious employment face lower protection for receiving annual health check-ups. Am J Ind Med 2012;55(10):884-892.

（32）原ひろ久. 非正規社員の企業内訓練についての分析. 日本労働研究雑誌 2011;607:33-48.

(33) Inoue A, Kawakami N, Tsuno K, Tomioka K, Nakanishi M. Organizational justice and psychological distress among permanent and non-permanent employees in Japan: a prospective cohort study. Int J Behav Med 2013;20(2):265276.

(34) Eibner C, Sturn R, Gresenz CR. Does relative deprivation predict the need for mental health services? J Ment Health Policy Econ 2004;7(4):167-275. 